\title{
Natural Resources Management Based on Local Social Welfare in Nagari Sungai Antuan, Lima Puluh Kota District
}

\author{
Nefilinda \\ Lecturer STKIP PGRI West Sumatra \\ Email: nefilinda@yahoo.com
}

\begin{abstract}
The purpose of this study is to reveal and analyze the management of natural resources based on local wisdom on the welfare of the community in Nagari Sungai Antuan, Lima Puluh Kota District. This research uses qualitative methods. Primary data were obtained from interviews with informants (community) and key informants (Wali Nagari, Niniak Mamak and Clean Water Management). The location of the research is in Nagari Sungai Antuan, Lima Puluh Kota district. The results of the study: forest management system or ulayat land is principled ganggam bauntuak based on kinship system, although the ownership of forest or ulayat land based on tribe. In case of a dispute between the tribe then settled by Niniak Mamak among the disputing tribes. The value of custom which feels thick here like gotong royong and often held musyawarah. Some local wisdom of society in Nagari Sungai Antuan are: 1) Manage gambier, 2) Manage mixed garden, 3) Manage paddy field and 4) Manage water resources.
\end{abstract}

Keywords: Natural Resources, Local Wisdom, People's Welfare

\section{Introduction}

Utilization of natural resources without regard to environmental carrying capacity and ecological functions can damage the environment. Suranto and Kusrahmadi (1990) stated that the environmental damage caused by human activities is generally caused by: 1) the ignorance of the community towards the consequences of their actions, such as the habit of disposing of garbage in the river or any unconscious place will cause pollution, 2) so it is unnoticed that environmental destructive activities continue like logging for burning bricks that have become work and family income, 3) lack of knowledge about the balance and function of ecosystems, such as the unpredictable use of pesticides resulting in the destruction of other organisms, 4) low awareness of environmental sustainability eg industrial disposal of waste regardless of its impact on the environment, 5) lack of environmental law and lack of legal sanction for violators.

A living culture in harmony with nature has been taught inheritance in the life of society. But the swift currents of globalization that result in the community life patterns consumptive make people less concerned with changes in environmental quality is rapidly declining. Culture loves the environment today is thinning, because people who have attitudes and behavior care for the environment have also been reduced. Should attitude and care to the environment starts from self-consciousness as part of the ecosystem, so that the ecosystem can be maintained. Awareness is already embedded in the culture of society in the form of local wisdom.

Minangkabau region consists of two parts, namely Luhak and Rantau. Luhak Nan Tigo, which consists of three districts: Tanah Datar (Luhak Nan Tuo), Lima Puluh Kota (Luhak Nan Tangah) and Agam (Luhak Nan Bungsu). Each district has many different Nagari and local wisdom. There is Nagari in Luhak Nan Tangah is Nagari Sungai Antuan is one of the villages producing gambier. Unfortunately, the management of gambier in the area, allegedly there is mixed with tapioca flour, sand and even fertilizer. Not only that Nagari Sungai Antuan community also there are trying as chicken breeders and under the cage there is a fish pond, but people use animal feed that uses chemicals, in the form of chicken drinks mixed with chemical substances to chicken quickly fat, this is expected to affect the surrounding environment, because the feed and mixture of chicken drinks provided are not according to the rules. Besides that, there are also people who are farming, on the sidelines of rice planting there is a time used to grow short-lived crops such 
as cucumbers, corn and chili but it is suspected that people use excessive chemical fertilizers, to the extent that people use fertilizers or pesticides when harvest with the assumption that the vegetables remain fresh.

\section{Method}

The location of the research is in Nagari Sungai Antuan, Lima Puluh Kota District. This study uses qualitative methods, this is done because it uses research questions, then more on the search for social phenomena in the form of opinions, descriptions and patterns. This is in accordance with the opinion of Herdiansyah (2010) which states that: "Qualitative research is a scientific research that aims to understand the phenomenon in a natural social context by emphasizing the process of interaction and deep communication between researchers with the phenomenon studied. This means that in qualitative research the main thing to do is the process of interaction and communication in order to understand the social phenomenon in depth. So qualitative research is often called naturalistic research because the research is done on natural condition. The natural condition is the condition as it is, not manipulated by the researchers, the researchers only show the object of research as it is. Some qualitative research according to Creswell (2009). Informants in this research are Nagari Sungai Antuan community and key informant are: Wali Nagari, Niniak Mamak and Clean Water Management.

\section{Results and Discussion}

Forest management system or ulayat land is principled ganggam bauntuak based on the family system, although the ownership of forest or Ulayat land based on tribe. In case of a dispute between the tribe then settled by Niniak Mamak among the disputing tribes. The value of custom which feels thick here like gotong royong and often held musyawarah. The potential of natural resources owned by Jorong Lubuak Simato is forest and water. The potential for forest is derived from gambier, while the potential of water resources comes from Bukik Sarasah and Bukik Batu Galeh, which is utilized by Lubuak Simato community for clean water, rice field, garden, fish and chicken farms.

The desire of the Minangkabau community to get a higher education level is now beginning to be seen from the behavior of parents who send their children to college, although using very limited funds, borrow to Village Unit Cooperatives (KUD) and sell cattle that exist in them, even they dare to sell what is at home for sale so they can send their children to college. In accordance with ndak ado kayu janjang di kapiang, essentially what is there sold or mortgaged for school children. In Naguan Sungai Antuan the habit of sending children to college is a pride. At Nagari Sungai Antuan, parents prepare for their children's educational costs with mangampo gambier results done in their fields. They mangampo if it is close to the payment of school fees for children, because mangampo activities or harvest gambier leaves ready to be harvested only once a month. Because there are also nagari communities who get shipment from their child in the rantau has not been included as income, so this small amount of income in the research results, which ranged from $\mathrm{Rp} 1,200,000$, - to $\mathrm{Rp} 1,600,000$. This amount is in the position below the Regional Minimum Wage for West Sumatera Province in 2017 of Rp 1,949,248, - (source of the Hour Wednesday, November 02, 2016).

The core of the results of interviews with the community, Wali Nagari, Niniak Mamak and Clean Water Management related to local wisdom (Keraf 2002) in managing natural resources are:

1. Increase knowledge to manage natural resources by using mass media (newspaper, television, radio and HP). Try it at home, if it can then share with the community around. This knowledge is also gained from training and counseling held by government and private parties, in relation to the management of natural resources. 
2. People have confidence, if the natural resources are well managed then many benefits obtained by the community. Such as managing forests, the people of Nagari Sungai Antuan are continuously getting water resources, although the neighboring Nagari has been drought, for the need of clean water, irrigating rice fields, gardens, fish and chicken livestock.

3. The Nagari Sungai Antuan Society understands what has been gained from previous schools, as well as from training and counseling, so that they can practice the management of natural resources well.

4. Finally, people become accustomed to managing natural resources. For example, most people as farmers, gardening and livestock, therefore require a lot of water, which is why people have been accustomed to manage forests to obtain water sources continuously.

Some local community wisdom practices in managing the natural resources in Nagari Sungai Antuan are:

1. Management of gambier plantations. The process of making gambier by the people Nagari Sungai Antuan does not use any chemicals, all natural, even the rest of the gambier sap extension derived from its leaves, made organic fertilizer by putting the rest of the leaves around the gambier tree trunk. This has become a hereditary custom in Nagari Sungai Antuan.

2. Management of mixed gardens. The community-run mixed gardens at Nagari Sungai Antuan are a habit. They mix short-lived crops for daily needs, such as chili, rimbang, and forest stands such as mahogany, coconut, petai, jengkol. In fact they complete the garden by raising livestock, such as honey, fish, chicken, cow and goat. Food sources for goats and cattle are taken from the grass around the garden and instead of livestock manure is used by the community for organic fertilizers, so the plants become fertile and environmentally preserved, impacting on the preservation of ecological cycles.

3. Wetland Management. In managing the rice fields, the Nagari Sungai Antuan people still use the traditional way of planting rice using human labor, given to mothers who need the work. Similarly, when harvesting, landowners prefer to employ housewives, thus earning additional income to meet the needs of his life. While the fertilizer used, have started using organic fertilizer, although not many. But the public admitted that using organic fertilizer the results of its pad more comfortable although the quantity is less but the price is more expensive, it is beneficial for the community and the sustainability of wetland ecosystem. This is evidenced by the number of eels in the community rice fields.

4. Management of water resources. The management of water resources conducted by the community in Jorong Lubuak Simato, by making the dam and flowing water using pipes to the community settlements. The distance of springs located in Bukit Sarasah to a reservoir is about $5 \mathrm{~km}$ with a slope of 70 degrees. All development work is done by the community in mutual assistance conducted by men and women. People who may apply for clean water are those who already have family latrines in their homes. If the community does not have a latrine on the grounds that they do not have the money to hire workers, the policy of the management of PBSABS (Board of Managers of Water and Sanitation Facility) is to conduct mutual assistance together with toilet making provided that the materials are provided. However, if people do not want to build family latrines at home, they can not subscribe to clean water managed by PBSABS.

\section{Conclusions}

Forest management system or ulayat land is principled ganggam bauntuak based on the family system, although the ownership of forest or ulayat land based on tribe. In case of a dispute between the tribe then settled by niniak mamak among the disputing tribes. The value of custom which feels thick here like gotong royong and often held musyawarah.. Local wisdom of the community is done by increasing 
knowledge, having confidence in managing natural resources, having a good understanding of natural resource management, finally people are accustomed to managing natural resources to meet the daily needs of farmers, gardening and livestock. Some local wisdom practices in Nagari Sungai Antuan are: managing gambier, managing mixed gardens, managing rice fields and managing water resources.

\section{References}

Creswell, John. W. (2009). Educational Research Planing, Conducting and Evaluating Quantitative and Qualitative Research. Pearson

Geertz, Clifford. (1973). The Interpretation of Cultures. New York: Basic Books, Inc., Publishers

Herdiansyah, Haris. (2010). Metodologi Penelitian Kualitatif untuk Ilmu-Ilmu Sosial. Jakarta.: Salemba Humanika

Keraf AS. (2002). Etika Lingkungan. Jakarta : Penerbit Buku Kompas

Nefilinda dan Zuriyani, E, (2014). Implementasi Kearifan Lokal Pengelolaan Sumberdaya Lahan Dalam Pembangunan Ekonomi Masyarakat Kota Padang. Jurnal Menara Ilmu. 8

Suhartini. (2009). Kajian Kearifan Lokal Dalam Pengelolaan Sumbardaya Alam dan Lingkungan. Prosiding Seminar Nasional Penelitian, Pendidikan dan Penerapan MIPA, Fakultas MIPA, Universtas Negeri Yogyakarta, 16 Mai 2009

Suranto \& Kusrahmadi, S.D. (1990). Upaya pembinaan Kepedulian Lingkungan Hidup. Cakrawala Pendidikan. Edisi Khusus Dies Natalis 